\title{
Design of Temperature Control for Herbal Dryer Based on PID Controller by Utilizing Renewable Energy Sources
}

\author{
Heriansyah $^{1}$, Swadexi Istiqphara ${ }^{2}$, Nur Adliani ${ }^{3}$ \\ Electrical Engineering, Department of Production, Industry and Information Technology, Institut Teknologi Sumatera, Terusan \\ Ryacudu Road, Way Hui, Lampung Selatan 35365, Indonesia ${ }^{1,2}$ \\ Pharmacy, Department of Science, Institut Teknologi Sumatera, Terusan Ryacudu Road, Ryacudu Street, Way Hui, Lampung \\ Selatan 35365, Indonesia ${ }^{3}$ \\ Email: heri@el.itera.ac.id
}

\begin{abstract}
Each type of plant has a different response to light, there are some plants that are very sensitive to direct sunlight and too high temperatures and some that are not. This research will take part in producing automatic medicinal plant drying products using the PID method and with the help of a microcontroller as an input and output processor, which will be used for the herbal medicine industry. The supply of load that will be used in this product comes from a combination of direct sunlight energy and solar panels to produce the right drying method and as needed. When the solar energy received by the dryer is excessive, the microcontroller will order the cooler to work and when the heat received is smaller than what has been set, the microcontroller will order the heater to operate. This product is expected to help the community and herbal medicine businesspeople to produce good quality drugs and can be mass produced. From the results of the research obtained is testing the heating control system, indicating that the control system can control the temperature in order to reach the specified target.
\end{abstract}

Keywords : Temperature, PID, Dryer, Pharmacognosy, Energy

\section{INTISARI}

Setiap jenis tanaman memiliki respons yang berbeda terhadap cahaya, ada beberapa tanaman yang sangat sensitif terhadap sinar matahari langsung dan suhu terlalu tinggi dan beberapa yang tidak. Penelitian ini akan mengambil bagian dalam memproduksi produk pengeringan tanaman obat otomatis menggunakan metode PID dan dengan bantuan mikrokontroler sebagai prosesor input dan output, yang akan digunakan untuk industri obat herbal. Pasokan beban yang akan digunakan dalam produk ini berasal dari kombinasi energi sinar matahari langsung dan panel surya untuk menghasilkan metode pengeringan yang tepat dan sesuai kebutuhan. Ketika energi matahari yang diterima oleh pengering berlebihan, mikrokontroler akan memerintahkan pendingin untuk bekerja dan ketika panas yang diterima lebih kecil dari yang telah diatur, mikrokontroler akan memerintahkan pemanas untuk beroperasi. Produk ini diharapkan dapat membantu masyarakat dan pelaku bisnis jamu untuk menghasilkan obat yang berkualitas baik dan dapat diproduksi secara massal. Dari hasil penelitian yang diperoleh adalah pengujian sistem kontrol pemanas, menunjukkan bahwa sistem kontrol dapat mengontrol suhu agar mencapai target yang ditentukan.

Kata kunci : Temperatur, PID, Dryer, Pharmacognosy, Energi

\section{INTRODUCTION}

Utilization of natural resources into herbal medicines in Indonesia is very little because the supporting facilities to develop medicinal plants to become phytopharmaca are still lacking. Postharvest techniques of herbal plants are less than optimal, such as the process of sorting, washing, draining, molding, drying, and processing to become various types of pharmaceutical products is a problem in itself. From the information above, drying techniques are a very important technique in producing highly qualified simplicia [1]. Based on these problems, this research will take part in developing a dryer that is able to dry various herbal plants. 
Existing natural drying system requires a long time to reduce water in herbal plants because it only relies on sunlight as an energy source in the drying process. Substitution of day and night and changing weather throughout the year is a problem in traditional drying systems. In rainy season, water in herbal plants can increase so that the plant has potential to become a medium for growing mushrooms, in addition to the drying process carried out in open spaces where herbal plants exposed to direct sunlight can cause the herbal plants to be too dry and will produce low quality simplicia.

Another focus in this research is to use renewable energy as an electricity supplier by designing an automatic dryer based on a microcontroller with a supply of loads sourced from a combination of direct sunlight energy and solar panels. Some variables that is observed include temperature in the dryer cabinet room, heater on / off status and heat dissipation, power produced by solar panels and power used by the system. Control method that will be used is the PID controller to produce optimal heat so that the power consumption becomes more effective and efficient.

Supply of load on this dryer comes from a combination of direct sunlight energy and solar panels. Solar panels are the most important component of a solar power plant. Using solar panels in this research aims to utilize sunlight that is always there throughout the year as a renewable energy source. The position of Indonesia on the equator produces a sunshine intensity of $4.8 \mathrm{~kW} /$ $\mathrm{m} 2$, so it is promising if it is used as an electricity source for the dryer products to be developed [2].

\section{RESEARCH METHOD}

\subsection{Herbal Dryer System}

The control method used in this research is PID. PID Method is the most popular control method, therefore many industries use the PID method as an industrial system control method. The PID method consists of 3 controllers namely
Proportional, Integral and Derivative [3]. The mathematical equations for PID controls are expressed in the following equation:

\begin{tabular}{|l|l|}
\hline$u_{p}=K_{p} * e$ & {$[1]$} \\
\hline$u_{d}=K_{d} \frac{d e}{d t}$ & {$[2]$} \\
\hline$u_{i}=K_{i} \int e d t$ & {$[3]$} \\
\hline$u_{\text {pid }}=u_{p}+u_{i}+u_{d}$ & {$[4]$} \\
\hline
\end{tabular}

The block diagram of herbal dryer system is shown in figure 1.

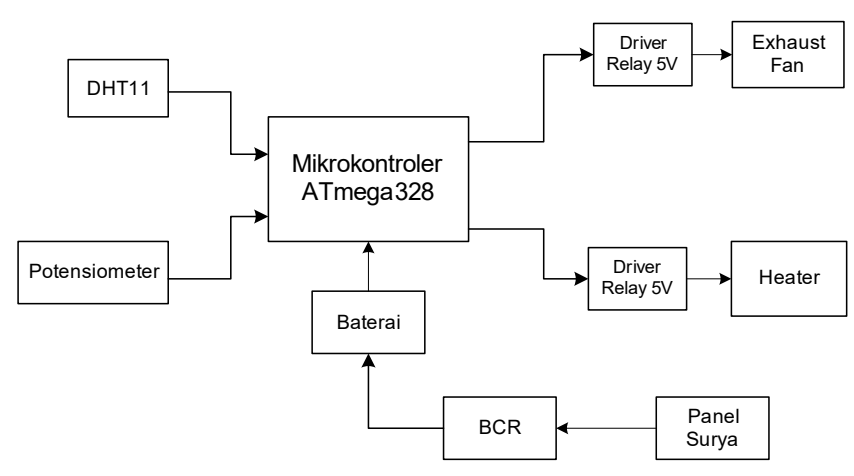

Fig. 1. Block diagram of herbal dryer system

As in fig. 1, this herbal dryer will work at a temperature set by user with a potentiometer. the temperature inside dryer cabinet will be read by DHT11 sensor and displayed on $16 \times 2$ Liquid Crystal Display (LCD). If the temperature generated from direct sunlight is less than set value, microcontroller will activate the heater, otherwise microcontroller will activate the exhaust fan to reduce heat to match the set value. The electricity produced by the solar panels will activate all the electronic components inside the dryer cabinet [4]. 
Jurnal ECOTIPE, Volume 6, No.2, Oktober 2019, Hal. 97-101

p-ISSN 2355-5068, e-ISSN 2622-4852

Akreditasi Kemenristekdikti (SINTA 4), SK. No.10/E/KPT/2019

DOI: 10.33019/ecotipe.v6i2.1392

\subsection{Design of Cabinet Dryer}

The drying cabinet of herbal plants has dimensions of $60 \times 50 \times 120 \mathrm{~cm}$ and the solar heat collector has dimensions of $100 \times 50 \times 20 \mathrm{~cm}$. The solar heat collector is made of glass with black zinc walls. The selection of materials and colors aims to get maximum heat absorption. The heat will be trapped under the glass and then will flow to the drying cabinet with the help of air coming from the ventilator at the bottom as shown in fig 2 .

It is designed using three trays with a distance between it is $20 \mathrm{~cm}$ and its top cover made of transparent glass. Each tray has a base that made of wire mesh to facilitate air circulation in transferring heat from the lower ventilator to the top of the cabinet ventilator. Just like a heat collector, the roof of the cabinet is made of glass and zinc for the wall.

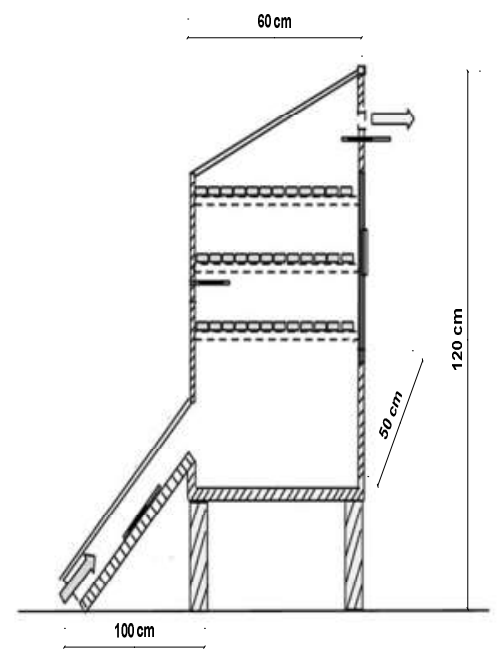

Fig.2. Design of herbal dryer's cabinet

In fig. 2 we can see that there is one air vent above the door and two at the bottom that works with exhaust fan to remove excess heat generated by direct solar heat. The two exhaust fans will remove excess heat from inside the cabinet if temperature exceeds a set value. Furthermore, the number of temperature sensors that will be installed in the drying cabinet is six. The six sensors are installed spread above, in the middle and under the cabinet. The aim is to increase the accuracy of temperature calculations.

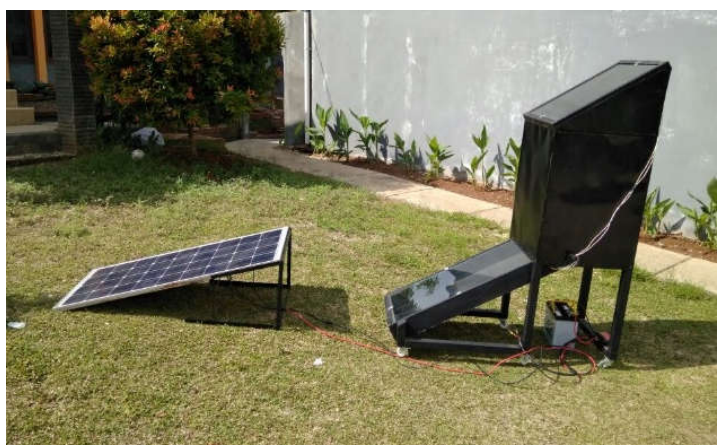

Fig.3. Prototype of herbal dryer's cabinet

The design results from Figure 2 are implemented into a prototype shown in Fig. 3. The prototype will be placed in an open field to be exposed to direct sunlight. It will be tested from 06:00 a.m to 06:00 p.m to find out the maximum heat obtained throughout the day. This prototype is equipped with an electronic circuit consisting of controllers, sensors, heating elements and exhaust fans. For power supplies, this device is equipped with solar panels and batteries that function to turn on heating elements and exhaust fans when the temperature in the cabinet is less or more than the threshold we have set. The solar panel devices used in this research consisted of $4 \times 100 \mathrm{~W}$ solar panels and 4x100AH batteries as shown in Fig. 4. The voltage used by a heater is an alternating current (AC) which requires an inverter to convert from a direct current (DC) to AC.

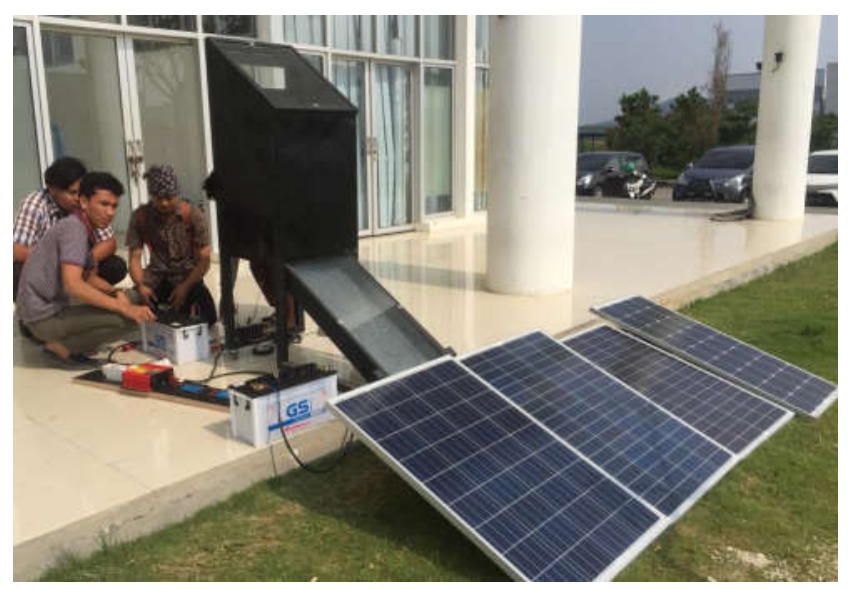


Fig.4. Prototype of herbal dryer's cabinet

\section{RESULTS AND DISCUSSION}

\subsection{Measurement results}

In this scenario, temperature in the cabinet will be measured using an electronic circuit. Temperature measurements in the cabinet will use DHT 11 sensors [4,5]. DHT11 will read the temperature in the cabinet room and its data will be sent into microcontroller. The microcontroller will control the temperature inside the cabinet so that the room temperature is still in the range of 45 - $60{ }^{0} \mathrm{C}$, it is an ideal temperature for optimal drying results. The microcontroller will read temperature in realtime to find out the latest temperature in cabinet room. If temperature exceeds the upper threshold, the fan will turn on to get rid of heat while if temperature does not reach the lower threshold, the heater will turn on to reach it. Table 1 shows the results of temperature control carried out by microcontroller [6].

Table 1. Temperature control in microcontroller

\begin{tabular}{cccc}
\hline No & Temperature & Fan & Heater \\
\hline 1 & $<45$ & OFF & ON \\
\hline 2 & $45-50$ & OFF & OFF \\
\hline 3 & $50-55$ & OFF & OFF \\
\hline 4 & $55-60$ & OFF & OFF \\
\hline 5 & $60>$ & ON & OFF \\
\hline
\end{tabular}

\subsection{Analysis}

We provide an analysis of temperature measurements at the outside cabinet dryer, inside cabinet dryer without electronic circuits and inside cabinet dryer with electronic circuits. The ambient temperature is shown in fig. 5. In that figure, we can see that the average of ambient temperatur is under the optimal drying threshold which is 38,25 ${ }^{0} \mathrm{C}$. it shows that the drying process in direct sunlight is not optimal and requires a long time to reduce water in herbal plants because it only relies on sunlight as an energy source and then produce less quality simplicia. Based on our measurement results, the ideal temperature that can be achieved to start drying herbs either with a dryer or in direct sunlight starts from 09:00 a.m to 02:00 p.m.

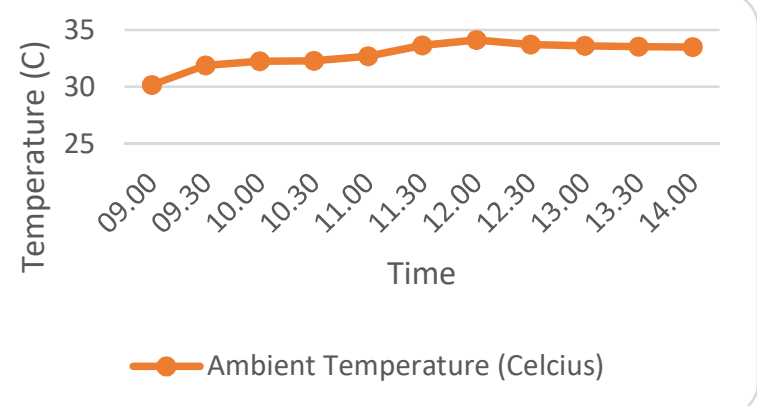

Fig.5. Graph of ambient temperature

Fig.6 shows the temperature comparison of cabinet dryer without electronic circuits and cabinet dryer with electronic circuits. Similar to the previous scenario, the ideal temperature obtained for drying occurs in the range of 09:00 a.m to 02:00 p.m with an average temperature of $50.6{ }^{0} \mathrm{C}$. Based on the graph, to get the optimal temperature, the operation of the herbal dryer outside of this time can be done by using an electronic circuit to turn on the artificial heater.

In this graph we see that the dryers with electronic circuits produces temperatures in the range of $45-60{ }^{0} \mathrm{C}$ from 09:00 a.m to 02:00 p.m but this did not happen to the dryer without electronic circuits. This is due to the functioning of the artificial heater to maintain the temperature inside the cabinet. If the temperature generated from direct sunlight is less than set value, microcontroller will activate the heater otherwise microcontroller will activate the exhaust fan to reduce heat to match the set value.

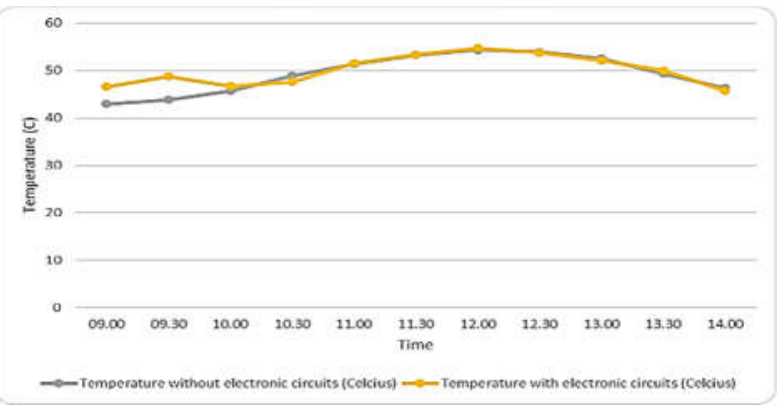


Jurnal ECOTIPE, Volume 6, No.2, Oktober 2019, Hal. 97-101

p-ISSN 2355-5068, e-ISSN 2622-4852

Akreditasi Kemenristekdikti (SINTA 4), SK. No.10/E/KPT/2019

DOI: 10.33019/ecotipe.v6i2.1392

Fig.6. Graph comparison of inside and outside temperature of the dryer cabinet

\section{CONCLUSION}

Based on the results of measurements and analysis, we found that The ideal time range for drying herbal plants is from 09:00 a.m to 02:00 p.m with an average temperature of $50,6{ }^{\circ} \mathrm{C}$, outside of this time, an electronic heater is needed to reach the ideal temperature. The average temperature difference outside cabinet with the inside cabinet is $16.57{ }^{\circ} \mathrm{C}$, so the drying process using a drying cabinet is more optimal than direct drying in the sun. From the result, the drying process more efficient if using microcontroller and PID controller able to maintain the set value temperature to drying herbal plant.

\section{REFERENCES}

[1] BPOM RI. 2014. Peraturan Kepala Badan Pengawas Obat dan Makanan No. 12 Tahun 2014 tentang Persyaratan Mutu Obat Tradisional. Jakarta : BPOM RI.

[2] Hernani dan Nurdjanah, R. 2009. Aspek Pengeringan dalam Mempertahankan Kandungan Metabolit Sekunder pada Tanaman Obat. Perkembangan Teknologi TRO 21 (2): 33-39.

[3] D-Robotics. 2010. DHT11 Temperature \& Humidity Sensor features a temperature \& humidity sensor complex with a calibrated digital signal output. http://www.droboticsonline.com (7 Juli 2010).

[4] Muller, J. and A. Heindl. "Drying of medicinal plants" in: R.J. Bogers, L.E. Craker, and D. Lange (eds.), "Medicinal and Aromatic Plants", Springer, The Netherlands, pp. 237252. 2006.

[5] Mairizwan and Hendro. "Perancangan dan Pembuatan Prototype Sistem Tracker Sel Surya untuk Mengikuti Arah gerak Matahari
Berbasis Mikrokontroler Atmega328". Prosiding Simposium Nasional Inovasi dan Pembelajaran Sains. Bandung: SNIPS. 2015.

[6] Sudhan, R.H., Kumar, M.G., Prakash, A.U., Devi, A.A.R., Sathiya, P. "Arduino Atmega328 Microcontroller". International Journal of Innovative Research in: Electrical, Electronics, Instrumentation and Control Engineering. Vol 3(4). pp. 27-29. 2015.

[7] Teikari, P., Raymond, P.N., Hemi, M., Kenneth, K., et al. "An inexpensive Arduinobased LED Stimulator System for Vision Research". Journal of Neuroscience Methods. pp. 227-236. 2012.

[8] W. Dehua, L. Pan, L. Bo, dan G. Zeng, "Water Quality Automatic Monitoring System Based on GPRS Data Communications," Procedia Eng., vol. 28, pp. 840-843, Jan 2012.

[9] N. Tajjudin, Z. Yusuf, M. H. Fazalul Rahiman and M. N. Taib, "Self tuning PID Controller for Steam Distillation Essential Oil Extraction System," in 6th International Colloquium on Signal Processing \& Its Applications (CSPA), Malacca City, Malaysia, 2010.

[10] Kenny, T. 2004. Sensor Fundamentals. In: Wilson, J.S. (ed.) Sensor Technology Handbook. Elsevier Science \& Technology. pp. 1-20. 